\title{
THE EFFECTS OF PURE MICROCYSTIN LR AND BIOMASS OF BLUE- GREEN ALGAE ON BLOOD INDICES OF CARP (Cyprinus carpio L.)
}

\author{
S. NAVRÁTIL, M. PALÍKOVÁ, V. VAJCOVÁ \\ Department of Game, Fish and Bee Diseases, \\ University of Veterinary and Pharmaceutical Sciences, Brno. Czech Republic
}

Received July 15, 1998

Accepted September 21, 1998

\begin{abstract}
Navrátil S., M. Palíková, V. Vajcová: The Effect of Pure Microcystin LR and Biomass of Blue-green Algae on Blood Indices of Carp (Cyprinus carpio L.). Acta vet. Brno 1998, 67: 273-279.

The aim of this work was to find out how the administration of the Microcystin LR and the biomass of blue-green algae with known amount of the Microcystin LR to juvenile carp influences indices of the red blood cells and activities of plasma enzymes.

The experimental fish were given either pure Microcystin LR or the biomass of blue-green algae with known amount of Microcystin LR. The administration of pure Microcystin LR at the dose of $400 \mu \mathrm{g}$ per $1 \mathrm{~kg}$ of body mass was conducted intraperitoneally, the biomass was applied per os. Microcystin LR volume in single doses was 3,300,600 and $1200 \mu \mathrm{g}$ per $1 \mathrm{~kg}$ of body mass. After 24 and $48 \mathrm{~h}$ blood was taken from fish by cardiac punction. The following indices of the blood were evaluated: the red blood cell count (RBC), haematocrit (PCV), haemoglobin $(\mathrm{Hb})$, mean corpuscular haemoglobin concentration (MCHC), mean corpuscular volume (MCV) and mean corpuscular haemoglobin (MCH). Activities of alanine aminotransferase (ALT), aspartate aminotransferase (AST) and lactate dehydrogenase (LDH) and total plasma proteins (TPP) were measured.

Significant changes ( $p \leq 0.05$ or $p \leq 0.01$ ) of RBC, PCV, Hb, MCV and $\mathrm{MCH}$ were found only after the application of the biomass of blue-green algae. These changes were usually within the physiological range of values variation or slightly under this range.

The activities of ALT, AST and LDH were mostly increased after all forms of administrations. The rate of increase depended on the route of administration, character of the material and amount of the toxin. A highly significant increase $(p \leq 0.01)$ of the activities of ALT $(60.07 \pm 36.89$ $\mu \mathrm{kat} \cdot \mathrm{l}^{-1}$, control $\left.2.98 \pm 1.58 \mu \mathrm{kat} \cdot \mathrm{l}^{-1}\right)$, AST $\left(38.91 \pm 15.51 \mu \mathrm{kat} \cdot \mathrm{l}^{-1}\right.$, control $\left.4.83 \pm 3.47 \mu \mathrm{kat} \cdot \mathrm{l}^{-1}\right)$ and LDH $\left(303.2 \pm 110.7 \mu \mathrm{kat} \cdot \mathrm{l}^{-1}\right.$. control $\left.10.4 \pm 5.1 \mu \mathrm{kat} \cdot \mathrm{l}^{-1}\right)$ was detected $24 \mathrm{~h}$ after i.p. administration of pure Microcystin LR. Significant ( $\leq \leq 0.05$ ) increase of the activities of ALT was detected after oral administration of 3,300 and $600 \mu \mathrm{g}$ of Microcystin LR per $1 \mathrm{~kg}$ of body mass. highly significant $(\mathrm{p} \leq 0.01)$ increase was detected after oral administration of $1200 \mu \mathrm{g}$. Significant $(p \leq 0.05)$ or highly significant $(p \leq 0.01)$ increase of the activities of AST and LDH was detected only after oral administration of $1200 \mu \mathrm{g}$ of Microcystin LR. These changes were above the range of the normal values variation.

The volume of TPP was significantly decreased $(\mathrm{p} \leq 0.01$ ) only $48 \mathrm{~h}$ after the administration of pure Microcystin LR $\left(19.38 \pm 4.90 \mathrm{~g} \cdot \mathrm{I}^{-1}\right.$, control $\left.30.68 \pm 4.10 \mathrm{~g} \cdot \mathrm{l}^{-1}\right)$. This change was at the limit of the normal values variation.

Our investigation found out the influence of the biomass of blue-green algae to indices of red blood cells and verified the influence of Microcystin LR and the biomass of blue-green algae to activities of plasma enzymes.
\end{abstract}

Fish, cyanotoxins, erythrocytes, plasma enzymes, total plasma protein

The blue-green algae can produce and incidentally release into their environment substances having a biological activity such as enzymes, vitamines, toxins, 
extracelullar polysaccharides, attractants, amino acids and other organic acids, antibiotics and hormones. Toxins of the blue-green algae (cyanotoxins) are secondary metabolic products (Maršálek and Turánek 1996). They may be divided according to various points of view. Carmichael (1992) divides the cyanotoxins according to methods of detection into cytotoxins and biotoxins. The cytotoxins are toxic to cell lines. The biotoxins are toxic to animal individuals. The biotoxins may be divided according to their biological activities into neurotoxins, hepatotoxins, cytotoxins, genotoxins, immunotoxins and embryotoxins (Maršálek and Turánek 1996). Biological activities of these toxins are often combined and a population of a single species of blue-green algae may be producing several toxins (Maršálek and Turánek 1996).

There are a number of different hepatotoxins produced by species and strains within the genera Anabaena, Cylindrospermopsis, Microcystis, Nodularia, Oscillatoria, Nostoc, Aphanizomenon, Gloeotrichia and Coelosphaerium. Hepatotoxins are the most common of the cyanobacterial toxins and the ones which are most commonly involved in acute toxicoses. They are slower-acting than the neurotoxins. Death can occur anywhere between 10 min to a few d after intoxication depending on a number of factors including size of animal, species, toxin dose, etc. (Ressom et al. 1994). Clinical signs in homoiotherm vertebrates are characterized by weakness, inappetence and shivering. There are necrobiotic processes in enlarged liver (Falconer and Yeung 1992). Kidneys are enlarged, too. Activities of alanine aminotrasferase (ALT), glutamine transpeptidase (GTP) and alkaline phosphatase (ALP) in blood serum are increased (Maršálek and Turánek 1996). The activity of gamma glutamyl transferase (GGT) is increased in man after drinking water from sources with massive development of water flowers of blue-green algae (Falconer et al. 1983). A suitable indicator of liver damage in sheep is glutamate dehydrogenase (GLDH). The activities of aspartate aminotransferase (AST) and lactate dehydrogenase (LDH) are increased, too (Carbis et al. 1994). Råbergh et al. (1991) described an increase of activities of AST, ALD and LDH after i. p. administration of microcystin LR to the carp.

Since there is no information available on possible changes of the red blood indices in fish exposed to or treated with microcystins, we decided to elucidate these questions.

\section{Materials and Methods}

A total of 83 juvenile carp with the average body mass of $168 \mathrm{~g}(110-380 \mathrm{~g})$ were used in this study. The fish had been kept at least for five days before the experiment at $18^{\circ} \mathrm{C}$ in laminated $1 \mathrm{~m}^{3}$ tanks equipped with aeration. The fish were fed commercial pelleted food for carp. Feeding of experimental fish had been always finished two days before the experiment. They experimental and control groups consisted of $6-8$ individuals each. The experiments lasted 24 and 48 h. For the i.p. administration we used pure Microcystin LR (Veterinary Research Institute, Brno) in a solution of HEPES at a dose of $400 \mu \mathrm{g}$ per $\mathrm{kg}$ of b.m. ( $1 \mathrm{ml}$ containing $100 \mu \mathrm{g}$ of Microcystin LR). Three kinds of biomass with known amount of Microcystin LR were used for oral administration. Analysis of the biomass was conducted by means of HPLC. Individual doses of the biomass were applied according to the content of Microcystin LR orally in doses of 3,300,600 and $1200 \mu \mathrm{g}$ per $\mathrm{kg}$ of body mass. The biomass was diluted in distilled water to obtain a volume of $3.0-3.6 \mathrm{ml}$. It was divided into two doses applied in 24-h intervals as to obtain a final dose of $1200 \mu \mathrm{g}$ of Microcystin LR. The red blood cells count (RBC), haematocrit (PCV), haemoglobin $(\mathrm{Hb})$, mean corpuscular haemoglobin concentration (MCHC), mean corpuscular volume (MCV) and mean corpuscular haemoglobin $(\mathrm{MCH})$ were determined by standard methods according to S vobodová et al. (1986). Total plasma proteins were determined using the commercial Bio-Lachema-Test (Lachema Diagnostika. Czech Republic). The activities of AST, ALT and LDH were determined by commercial tests of HUMAN (Germany).

The results were evaluated by Student's t-test. 


\section{Results}

The results are given in the Tables 1, 2, 3, 4 and 5.

Table 1

Red blood cells count (RBC) and haematocrit (PCV)

\begin{tabular}{|c|c|c|c|c|c|c|c|c|c|c|c|c|}
\hline & \multicolumn{5}{|c|}{$\operatorname{RBC}\left(\mathrm{t} \cdot \mathrm{l}^{-1}\right)$} & \multicolumn{5}{|c|}{$\operatorname{PCV}\left(1 \cdot 1^{-1}\right)$} \\
\hline & & & 3 & 300 & 400ip & 600 & 1200 & 3 & 300 & 400ip & 600 & 1200 \\
\hline & & & \multicolumn{10}{|c|}{ Microcystin LR $\mu \mathrm{g} \cdot \mathrm{kg}^{-1}$ of body mass } \\
\hline \multirow[t]{4}{*}{$24 \mathrm{~h}$} & exp. & mean & 1.40 & 1.34 & 1.33 & 1.10 & 1.45 & 0.20 & 0.20 & 0.20 & 0.26 & 0.21 \\
\hline & & $S D$ & 0.30 & 0.31 & 0.36 & 0.15 & 0.27 & 0.03 & 0.05 & 0.06 & 0.04 & 0.04 \\
\hline & control & mean & 1.76 & 1.76 & 1.22 & 1.01 & 1.45 & 0.25 & 0.25 & 0.21 & 0.21 & 0.20 \\
\hline & & $S D$ & 0.40 & 0.40 & 0.33 & 0.27 & 0.31 & 0.04 & 0.04 & 0.05 & 0.03 & 0.04 \\
\hline \multirow[t]{4}{*}{$48 \mathrm{~h}$} & exp. & mean & 1.20 & 1.19 & 1.10 & 1.52 & 0.96 & 0.19 & 0.16 & 0.21 & 0.18 & 0.16 \\
\hline & & $S D$ & 0.15 & 0.33 & 0.27 & 0.37 & 0.38 & 0.02 & 0.03 & 0.06 & 0.02 & 0.07 \\
\hline & control & mean & 1.45 & 1.45 & 1.29 & 1.01 & 1.45 & 0.23 & 0.23 & 0.21 & 0.21 & 0.20 \\
\hline & & $S D$ & 0.17 & 0.17 & 0.24 & 0.27 & 0.31 & 0.02 & 0.02 & 0.03 & 0.03 & 0.04 \\
\hline
\end{tabular}

$$
\begin{aligned}
& p \leq 0.01 \\
& p \leq 0.05
\end{aligned}
$$

Statistically significant ( $p \leq 0.05$ or $p \leq 0.01$ ) changes of $\mathrm{RBC}, \mathrm{PCV}, \mathrm{Hb}, \mathrm{MCHC}, \mathrm{MCV}$ and $\mathrm{MCH}$ were found only after oral administration of the biomass containing Microcystin LR. These changes were influenced by the dose and the time after treatment. They have often shown various trends. $R B C$ significantly $(\mathrm{p} \leq 0.05)$ decreased after low but also high doses $(1200 \mu \mathrm{g}$ of Microcystin LR), while they were significantly $(\mathrm{p} \leq 0.05)$ increased $48 \mathrm{~h}$ after the dose of $600 \mu \mathrm{g}$ per $1 \mathrm{~kg}$ of body mass. PCV was significantly ( $\leq 0.05$ or $\mathrm{p} \leq 0.01)$ decreased after low

Table 2

\begin{tabular}{|c|c|c|c|c|c|c|c|c|c|c|c|c|}
\hline & \multicolumn{5}{|c|}{$\mathrm{Hb}\left(\mathrm{g} \cdot 1^{-1}\right)$} & \multicolumn{5}{|c|}{$\operatorname{MCHC}\left(1 \cdot 1^{-1}\right)$} \\
\hline & & & 3 & 300 & 400ip & 600 & 1200 & 3 & 300 & 400ip & 600 & 1200 \\
\hline & & & \multicolumn{10}{|c|}{ Microcystin LR $\mu \mathrm{g} \cdot \mathrm{kg}^{-1}$ of body mass } \\
\hline \multirow[t]{4}{*}{$24 \mathrm{~h}$} & exp. & mean & 60.87 & 56.73 & 45.86 & 46.44 & 53.53 & 0.31 & 0.29 & 0.23 & 0.18 & 0.26 \\
\hline & & $S D$ & 8.89 & 15.24 & 16.49 & 7.19 & 12.47 & 0.03 & 0.02 & 0.04 & 0.04 & 0.08 \\
\hline & control & mean & 74.30 & 74.30 & 47.03 & 45.83 & 44.32 & 0.29 & 0.29 & 0.24 & 0.21 & 0.22 \\
\hline & & $S D$ & 12.19 & 12.19 & 13.90 & 11.56 & 8.96 & 0.02 & 0.02 & 0.04 & 0.03 & 0.03 \\
\hline \multirow[t]{4}{*}{$48 \mathrm{~h}$} & exp. & mean & 80.79 & 60.00 & 57.22 & 42.87 & 47.55 & 0.43 & 0.37 & 0.28 & 0.24 & 0.29 \\
\hline & & $S D$ & 9.31 & 13.71 & 21.28 & 11.2 & 14.09 & 0.04 & 0.04 & 0.07 & 0.05 & 0.05 \\
\hline & control & mean & 97.68 & 97.68 & 74.21 & 45.83 & 44.32 & 0.44 & 0.44 & 0.35 & 0.21 & 0.22 \\
\hline & & $S D$ & 16.07 & 16.07 & 18.92 & 11.56 & 8.96 & 0.10 & 0.10 & 0.04 & 0.03 & 0.03 \\
\hline
\end{tabular}

Haemoglobin $(\mathrm{Hb})$ and mean corpuscular haemoglobin concentration (MCHC)

$\mathrm{p} \leq 0.01$

$\mathrm{p} \leq 0.05$ 
doses and significantly $(\mathrm{p} \leq 0.01)$ increased $24 \mathrm{~h}$ after the dose of $600 \mu \mathrm{g}$ per $1 \mathrm{~kg}$ of body mass. No changes of PCV were found after the dose of $1200 \mu \mathrm{g}$ of Microcystin LR. Hb was significantly ( $\mathrm{p} \leq 0.05$ or $\mathrm{p} \leq 0.01$ ) decreased only after the dose of 3 and $300 \mu \mathrm{g}$ per $\mathrm{kg}$ of body mass. The MCHC was significantly ( $\mathrm{p} \leq 0.01$ ) increased only $48 \mathrm{~h}$ after the dose of $1200 \mu \mathrm{g}$ per $\mathrm{kg}$ of body mass. The MCV was significantly $(\mathrm{p} \leq 0.01)$ decreased $48 \mathrm{~h}$ after the dose of $600 \mu \mathrm{g}$ per $\mathrm{kg}$ of body mass. This variable was significantly $(\mathrm{p} \leq 0.05)$ increased also after the dose of $1200 \mu \mathrm{g}$ of Microcystin LR. MCH was significantly $(\mathrm{p} \leq 0.05)$ decreased $48 \mathrm{~h}$ after the dose of

Table 3

Mean corpuscular volume (MCV) and mean corpuscular haemoglobin (MCH)

\begin{tabular}{|c|c|c|c|c|c|c|c|c|c|c|c|c|}
\hline & \multicolumn{5}{|c|}{$\mathrm{MCV}$ (fl) } & \multicolumn{5}{|c|}{$\mathrm{MCH}(\mathrm{pg})$} \\
\hline & & & 3 & 300 & 400ip & 600 & 1200 & 3 & 300 & 400ip & 600 & 1200 \\
\hline & & & \multicolumn{10}{|c|}{ Microcystin LR $\mu \mathrm{g} \cdot \mathrm{kg}^{-1}$ of body mass } \\
\hline \multirow[t]{4}{*}{$24 \mathrm{~h}$} & exp. & mean & 145.6 & 146.5 & 170.5 & 232.6 & 150.7 & 44.53 & 42.06 & 38.02 & 42.88 & 38.05 \\
\hline & & $S D$ & 18.5 & 17.2 & 36.4 & 11.37 & 26.41 & 6.41 & 5.47 & 4.67 & 9.38 & 11.50 \\
\hline & control & mean & 147.1 & 147.1 & 173.2 & 216.3 & 141.9 & 42.08 & 42.08 & 38.83 & 45.88 & 30.83 \\
\hline & & $S D$ & 17.1 & 17.1 & 15.7 & 34.95 & 30.00 & 5.78 & 5.78 & 5.96 & 7.80 & 4.99 \\
\hline \multirow[t]{4}{*}{$48 \mathrm{~h}$} & exp. & mean & 158.8 & 140.6 & 184.3 & 124.2 & 182.7 & 68.15 & 51.83 & 50.97 & 29.81 & 53.00 \\
\hline & & $S D$ & 12.5 & 29.8 & 20.1 & 22.84 & 40.17 & 9.79 & 9.04 & 12.86 & 10.47 & 15.3 \\
\hline & control & mean & 154.2 & 154.2 & 168.6 & 216.3 & 141.9 & 68.89 & 68.89 & 57.65 & 45.88 & 30.83 \\
\hline & & $S D$ & 24.5 & 24.5 & 28.4 & 34.95 & 30.00 & 15.89 & 15.89 & 10.26 & 7.80 & 4.99 \\
\hline
\end{tabular}

$$
\begin{aligned}
& p \leq 0.01 \\
& p \leq 0.05
\end{aligned}
$$

$300 \mu \mathrm{g}$ and decreased $(\mathrm{p} \leq 0.01) 48 \mathrm{~h}$ after the application of $600 \mu \mathrm{g}$ of Microcystin LR per $1 \mathrm{~kg}$ of body mass. This variable was increased ( $\mathrm{p} \leq 0.01) 48 \mathrm{~h}$ after the application of $1200 \mu \mathrm{g}$ of Microcystin LR per $1 \mathrm{~kg}$ of body mass. The changes of RBC, PCV, $\mathrm{Hb}, \mathrm{MCHC}, \mathrm{MCV}$ and $\mathrm{MCH}$ were usually within the range of physiological values variation or under this range. Some values of $\mathrm{PCV}, \mathrm{Hb}$. MCHC, MCV and MHC were also under this range in control fish.

Table 4

\begin{tabular}{|c|c|c|c|c|c|c|c|c|c|c|c|c|}
\hline & \multicolumn{5}{|c|}{$\operatorname{TPP}\left(g \cdot l^{-1}\right)$} & \multicolumn{5}{|c|}{$\operatorname{ALT}\left(\mu \mathrm{kat} \cdot \mathrm{l}^{-1}\right)$} \\
\hline & & & 3 & 300 & 400ip & 600 & 1200 & 3 & 300 & 400ip & 600 & 1200 \\
\hline & & & \multicolumn{10}{|c|}{ Microcystin LR $\mu \mathrm{g} \cdot \mathrm{kg}^{-1}$ of body mass } \\
\hline \multirow[t]{4}{*}{$24 \mathrm{~h}$} & exp. & mean & 26.30 & 26.10 & 23.76 & 29.29 & 30.37 & 1.62 & 1.26 & 60.07 & 5.22 & 40.39 \\
\hline & & $S D$ & 2.10 & 1.80 & 4.00 & 4.41 & 4.70 & 0.47 & 0.35 & 36.89 & 2.59 & 21.71 \\
\hline & control & mean & 25.20 & 25.20 & 27.30 & 28.60 & 30.34 & 1.24 & 1.24 & 2.98 & 2.34 & 2.13 \\
\hline & & $S D$ & 1.80 & 1.80 & 3.54 & 4.23 & 4.05 & 0.41 & 0.41 & 1.58 & 1.19 & 0.83 \\
\hline \multirow[t]{4}{*}{$48 \mathrm{~h}$} & exp. & mean & 25.30 & 24.60 & 19.38 & 24.57 & 29.19 & 7.82 & 7.10 & 80.96 & 24.79 & 50.00 \\
\hline & & $S D$ & 2.00 & 2.00 & 4.90 & 2.80 & 4.59 & 6.80 & 5.85 & 61.55 & 29.41 & 28.26 \\
\hline & control & mean & 25.60 & 25.60 & 30.68 & 28.60 & 30.34 & 0.85 & 0.85 & 5.22 & 2.34 & 2.13 \\
\hline & & $S D$ & 2.60 & 2.60 & 4.10 & 4.23 & 4.05 & 0.22 & 0.22 & 4.88 & 1.19 & 0.83 \\
\hline
\end{tabular}

Total plasma proteins (TPP) and activities of alanine aminotransferase (ALT)

$\mathrm{p} \leq 0.01$ 
TPP were decreased only after i.p. of pure Microcystin LR ( $p \leq 0.01)$. This change was on the limit of the normal values variation.

The activities of ALT, AST and LDH were practically increased after all routes of administration. The rate of increase depended on the method of administration, the character of the material and the amount of the toxin. A highly significant increase $(p \leq 0.01)$ of ALT, AST and LDH activities was detected $24 \mathrm{~h}$ after i.p. administration of the pure Microcystin LR. Significant $(\mathrm{p} \leq 0.05)$ increase of the activities of ALT was detected after oral administration of 3, 300 and $600 \mu \mathrm{g}$ of Microcystin LR., highly significant ( $\leq \leq 0.01$ ) increase was detected after oral administration of $1200 \mu \mathrm{g}$ of Microcystin LR. Significant $(p \leq 0.05)$ or highly significant $(p \leq 0.01)$ increase of AST and LDH activities was detected only after oral administration of $1200 \mu \mathrm{g}$ of Microcystin LR per $1 \mathrm{~kg}$ of body mass. These changes were above the range of the normal values variation.

Table 5

Activities of aspartate aminotransferase (AST) and lactate dehydrogenase (LDH)

\begin{tabular}{|c|c|c|c|c|c|c|c|c|c|c|c|c|}
\hline & \multicolumn{5}{|c|}{$\operatorname{AST}\left(\mu \mathrm{kat} \cdot \mathrm{l}^{-1}\right)$} & \multicolumn{5}{|c|}{$\mathrm{LDH}\left(\mu \mathrm{kat} \cdot \mathrm{l}^{-1}\right)$} \\
\hline & & & 3 & 300 & 400ip & 600 & 1200 & 3 & 300 & 400ip & 600 & 1200 \\
\hline & & & \multicolumn{10}{|c|}{ Microcystin LR $\mu \mathrm{g} \cdot \mathrm{kg}^{-1}$ of body mass } \\
\hline \multirow[t]{4}{*}{$24 \mathrm{~h}$} & exp. & mean & 5.16 & 6.71 & 38.91 & 5.86 & 13.35 & 46.7 & 42.8 & 303.2 & 34.3 & 131.9 \\
\hline & & $S D$ & 2.15 & 5.26 & 15.51 & 5.55 & 5.38 & 27.0 & 20.8 & 110.7 & 36.0 & 67.9 \\
\hline & control & mean & 3.61 & 3.61 & 4.83 & 4.97 & 4.97 & 25.4 & 25.4 & 10.4 & 27.2 & 23.0 \\
\hline & & $S D$ & 3.07 & 3.07 & 3.47 & 1.56 & 4.98 & 17.6 & 17.6 & 5.1 & 10.1 & 17.6 \\
\hline \multirow[t]{4}{*}{$48 \mathrm{~h}$} & exp. & mean & 4.82 & 4.63 & 34.64 & 8.77 & 13.20 & 35.9 & 41.00 & 235.5 & 97.9 & 135.4 \\
\hline & & $S D$ & 2.16 & 2.57 & 10.12 & 9.44 & 5.93 & 21.9 & 28.8 & 137.8 & 103.4 & 84.0 \\
\hline & control & mean & 4.77 & 4.77 & 11.90 & 4.97 & 4.97 & 23.4 & 23.4 & 20.3 & 27.2 & 23.0 \\
\hline & & $S D$ & 2.93 & 2.93 & 15.38 & 1.56 & 4.98 & 10.9 & 10.9 & 21.7 & 10.1 & 17.6 \\
\hline
\end{tabular}

$\mathrm{p} \leq 0.01$

$\mathrm{p} \leq 0.05$

\section{Discussion}

There is no information in the literature on changes of RBC, PCV, Hb, MCHC, MCV and $\mathrm{MCH}$ in fish after the administration of microcystins. Significant changes of these variables only after oral administration of Microcystin LR in biomass of blue-green algae may be explained by a certain amount of other substances present in this biomass. Various trends of $\mathrm{RBC}$ and PCV may be explained by patho-morphological findings. These comprise extensive haemorrhage in the skin, in the eyes, in hepatopancreas and in swim bladder. These blood losses were compensated for by release of young stages of erythrocytes after the dose of $600 \mu \mathrm{g}$ of the Microcystin LR per $1 \mathrm{~kg}$ of body mass. However, this compensational mechanism was probably exhausted after the dose of $1200 \mu \mathrm{g}$ per $\mathrm{kg}$ of body mass. The changes of MCV and $\mathrm{MCH}$ corresponded to the described mechanism. These changes of the red blood cell indices were mostly ranging within the variation of physiological values or lower. PCV $, \mathrm{Hb}, \mathrm{MCHC}, \mathrm{MCV}$ and MCV were ranging below this range also in control fish. Their evaluation is therefore very difficult.

The activities of ALT, AST and LDH were mostly increased. These findings correspond with literature data (Råbergh et al. 1991). The changes were ranging above the normal values ( Svobodová et al. 1986). 
It is very difficult to explain the decreased the total plasma protein. S vobodova et al. (1997) described similar changes after the administration of some toxic substances.

Our investigation elucidated the influence of the biomass of blue-green algae on red blood cell indices and verified the influence of Microcystin LR and the biomass of blue-green algae on activities of plasma enzymes.

\section{Vliv čistého microcystinu LR a biomasy sinic na krevní ukazatele kapra (Cyprinus carpio L.)}

Cílem práce bylo zjistit vliv aplikace microcystinu LR a biomasy sinic se známým obsahem microcystinu LR na ukazatele červeného krevního obrazu a aktivitu plasmatických enzymů u kapři násady.

Pokusným rybám byl aplikován čistý microcystin LR nebo biomasa sinic se známým obsahem microcystinu LR. Aplikace čistého microcystinu LR v dávce $400 \mu \mathrm{g} \cdot \mathrm{kg}^{-1}$ ž. h. byla prováděna intraperitoneálně, biomasa byla aplikována perorálně. Obsah microcystinu LR v jednotlivých dávkách byl 3, 300, 600 a $1200 \mu \mathrm{g} \cdot \mathrm{kg}^{-1} \check{z}$. h. Po 24 a 48 h po aplikaci byla rybám odebrána krev. Byl stanovován počet erytrocytů (RBC), hematokrit (PCV), hemoglobin ( $\mathrm{Hb})$ a výpočtem dále hemoglobin ery trocytu (MCH), objem erytrocytu (MCV) a střední barevná koncentace (MCHC). Dále byla zjištována aktivita alaninaminotransferázy (ALT), aspartát-aminotransferázy (AST) a laktát-dehydrogenázy (LDH). Bylo zjištováno množství celkových bílkovin krevní plasmy (TPP).

$\mathrm{V}$ červeném krevním obrazu došlo ke statisticky významným změnám ( $\mathrm{p} \leq 0,05$ nebo $\mathrm{p} \leq 0,01$ ) RBC, PCV, Hb, MCV a MCH. Tyto změny byly zaznamenány pouze po aplikaci biomas sinic a pohybovaly se obvykle $v$ rámci variačního rozpětí normálních hodnot nebo pod tímto rozpětím.

Aktivity ALT, AST a LDH byly většinou zvýšené. Stupeň zvýšení byl závislý na způsobu aplikace, charakteru aplikované látky a na množství toxinu. Vysoce významné zvýšení (p $\leq 0,01)$ aktivity $\operatorname{ALT}\left(60,07 \pm 36,89 \mu \mathrm{kat} \cdot \mathrm{l}^{-1}\right.$, kontrola 2,98 $\left.\pm 1,58 \mu \mathrm{kat} \cdot \mathrm{l}^{-1}\right)$, AST $\left(38,91 \pm 15,51 \mu \mathrm{kat} \cdot \mathrm{l}^{-1}\right.$, kontrola 4,83 $\left.\pm 3,47 \mu \mathrm{kat} \cdot \mathrm{l}^{-1}\right)$ a $\operatorname{LDH}\left(303,2 \pm 110,7 \mu \mathrm{kat} \cdot \mathrm{l}^{-1}\right.$, kontrola $10,4 \pm 5,1 \mu \mathrm{kat} \cdot \mathrm{1}^{-1}$ ) bylo zjištěno za $24 \mathrm{~h}$ po i.p. aplikaci čistého microcystinu LR. Významné ( $\mathrm{p} \leq 0,05)$ zvýšení aktivity ALT bylo zjištěno po perorální aplikaci v dávkách 3 , 300 a $600 \mathrm{Kg}$ microcystinu $\mathrm{LR} \cdot \mathrm{kg}^{-1}$ ž. h., vysoce významné (p $\left.\leq 0,01\right)$ zvýšení aktivity ALT bylo zjištěno po perorální aplikaci $1200 \mu \mathrm{g}$ microcystinu $\mathrm{LR} \mathrm{kg}^{-1} \mathrm{z}$. h. Významné (p $\leq$ $0,05)$ nebo vysoce významné ( $\mathrm{p} \leq 0,01)$ zvýšení aktivity AST a LDH bylo zjištěno jen po perorální aplikaci $1200 \mu \mathrm{g}$ microcystinu $\mathrm{LR} \cdot \mathrm{kg}^{-1}$ ž. h. Uvedené změny se pohybovaly nad hranicí variačního rozpětí normálních hodnot.

TPP se vysoce významně $(\mathrm{p} \leq 0,01)$ snížily jen za 48 hodin po aplikaci čistého microcystinu LR $\left(19,38 \pm 4,90 \mathrm{~g} \cdot \mathrm{l}^{-1}\right.$, kontrola $\left.30,68 \pm 4,10 \mathrm{~g} \cdot \mathrm{l}^{-1}\right)$. Toto snížení bylo na hranici variačního rozpětí normálních hodnot.

Zjistili jsme vliv biomasy sinic na ukazatele červeného krevního obrazu a potvrdili vliv microcystinu LR a biomasy sinic na aktivitu plasmatických enzymů.

\section{Acknowledgement}

This work was supported by the Fund of Development of Universities of the Ministry of Education, Youth and Sports of the Czech Republic (Project No. 32/97), by the internal grand of the University of Veterinary and Pharmaceutical Sciences Brno and by the Nadatio Flos-aquae.

\section{References}

CARMICHAEL, W. W. 1992: Cyanobacteria secondary metabolities - the cyanotoxins. A review. J. Appl. Bacteriol. 72: 445-459 
CARBIS, C. R. , SIMONS, J. A., MITCHELL, G. F., ANDERSON, J. W., McCAULEY, I. 1994: A biochemical profile for predicting the chronic exposure of sheep to Microcystis aeruginosa, an hepatotoxic species of bluegreen alga. Res. Vet. Sci. 57: 310-316

FALCONER, I. R., BERESDORF, A. M. - RUNNEGAR, M. T. C. 1983: Evidence of liver damage by toxin from blue-green alga Microcystis aeruginosa. J. Med. Aust. 1: $511-514$

FALCONER, I. R., YEUNG, D. S. K. 1992: Cytoskeletal changes in hepatocytes induced by Microcystis toxins and their relation to hyperphosphorylation of cell proteins. Chem. Biol. Interactions 81: 181-196

MARSÁLEK, B., TURÁNEK, J. 1996: Biologicky aktivní látky produkované sinicemi vodního květu. In: Vodní květy sinic. Ed.: MARŚÁLEK - KERŚNER - MARVAN, Nadatio flos-aquae, Brno, pp. 86-100

RÅBERGH, C., M., I., BYLUND, G., ERIKSSON, J. E. 1991: Histopathological effects of microcystin LR, a cyclic peptide toxin from the cyanobacterium (blue-green alga) Microcystis aeruginosa on common carp (Cyprinus carpio L.). Aquatic Toxicology 20: 131-146

RESSOM, R., SOONG, F. S.. FITZGERALD, J., TURCZYNOWICZ, L., EL SAADI, O., RODER, D., MAYNARD, T., FALCONER, I. 1994: Health effects of toxic cyanobacteria (blue-green algae). NHMRC, Canberra, $108 \mathrm{p}$.

SVOBODOVÁ, Z., PRAVDA, D., PALÁCKKOVÁ, J. 1986: Jednotné metody hematologického vyšetřování ryb. Edice metodik VÚRH ve Vodñanech, Vodñany, $36 \mathrm{p}$.

SVOBODOVÁ, Z., GROCH, L., FLAJŠHANS, M., VYKUSOVÁ, B., MÁCHOVÁ, J. 1997: The effect of longterm therapeutic bath of malachite green on common carp (Cyprinus carpio, L.). Acta vet. Brno 66: 111-117 